\title{
Treating Chronic Pain with a Plant-Based Diet - a Case Report
}

\author{
Stewart Rose and Amanda Strombom* \\ Plant-Based Diets in Medicine, USA
}

Submission: December 10, 2019; Published: December 18, 2019

*Corresponding author: Amanda Strombom, Plant-Based Diets in Medicine, 12819 SE 38th St, \#427, Bellevue, WA 98006, USA

\begin{abstract}
Treatment with a plant-based diet has already been shown to be safe and effective both for several pathologies with chronic pain as a symptom. Here we describe the case of a 41-year old male patient who had been injured at work in 2009 and suffered from pain and restricted range of motion in his lumbar spine and legs for three years. During that time, he was treated with pain medications, including epidural steroid injections and a short course of opioids. The patient then underwent L4-L5 microdiscectomy followed by lumbar laminectomy and L5-S1 discectomy, fusion and was given a series of steroid epidural injections. However, he remained with very significant pain, limited range of motion and was unable to work. The patient was then referred to a physical and rehabilitative physician who prescribed a plant-based diet. Recognizing that standard treatment did not achieve the results he hoped for, the patient was open to the idea and embraced it whole-heartedly. He was also encouraged to eliminate caffeine and alcohol, and to rely on water for hydration, and to start some gentle physical therapy. Within 2 weeks, the patient noticed a reduction of symptoms. Within a month he no longer experienced back pain and his range of motion was improving. He gradually lost $50 \mathrm{lbs}$ and regained the ability to walk and stand straight. Within three months he was able to resume work. The patient was very satisfied with the role of the plant-based diet in relieving his symptoms and enabling him to resume a normal and productive life.
\end{abstract}

\section{Introduction}

Chronic pain, one of the most common reasons adults seek medical care [1], has been linked to restrictions in mobility and daily activities [2,3], dependence on opioids [4], anxiety and depression [2], and poor perceived health or reduced quality of life [2,4]. Eight percent of U.S. adults (19.6 million) had high-impact chronic pain, with higher prevalence of both chronic pain and high-impact chronic pain reported among women, older adults, previously but not currently employed adults, adults living in poverty, and rural residents [5]. Long term treatment with opioids has become a growing concern. Long term use of other medications often used as an adjunct can also be problematic. New treatments are needed for the treatment of chronic pain. Consumption of a plant-based diet has shown positive improvements in chronic pain and function [6]. A plant-based diet has been shown to be a safe and effective treatment in several specific pathologies which present with chronic pain as a symptom. This includes rheumatoid arthritis [7], diabetic peripheral neuropathy $[8,9]$, fibromyalgia [10-12], and angina pectoris [13].

\section{Case Report}

The patient, a 41-yr old male carpenter married with 2 dependent children, had been injured at work in December 2009. He was lifting something at work when he felt a sudden onset lumbar pain extending to the left lower limb. His Range of Motion (ROM) at the lumbar spine was restricted in flexion to 65 degrees. He had a decreased left ankle jerk reflex, and decreased sensation at the lateral aspect of the left foot. An MRI showed a lumbar disc herniation at L4-L5. At that time his BMI was 31.3, blood pressure was $148 / 88$. A former smoker, he drank wine on occasion and consumed caffeine throughout the day. He had a family history of diabetes mellitus (father) and hypertension (mother). He was taking Lisinopril (10mg daily) and ibuprofen (800mg x 3 daily). He was put on light duty at work and tried physical therapy and increased medications. He was given a series of 3 epidural steroid injections, but these resulted in diminishing returns and his pain returned a month after last epidural. In June 2010, he underwent L4-L5 microdiscectomy and a short course of opioids. He experienced initial improvement, but recurrent lumbar pain had returned by Sept 2010. In October 2010, he underwent lumbar laminectomy and L5-S1 discectomy, but he continued to have post-operative pain and chronic radicular symptoms in both legs. An MRI showed degenerative changes in lumbar spine, with epidural fibrosis causing lateral recess stenosis L3-S1. A lumbar discography was performed, and lumbar spinal fusion recommended. In Jan 2011, he underwent posterior lumbar spinal fusion with pedicle screw instrumentation, but he experienced ongoing chronic pain despite the corrective surgery. 


\section{Results}

In May 2012, he was referred to a physical and rehabilitative physician. At that time, he could not stand straight, could barely lift 15lbs, and experienced extreme 10/10 pain in spine and legs. He had gained additional 30lbs due to immobility. The concept of plant-based anti-inflammatory diet was introduced to him and he was encouraged to drink water for hydration, and to restrict alcohol and caffeine to reduce neurotoxins. He started some gentle physical therapy. He was desperate for a solution, and so embraced the plant-based diet wholeheartedly. Within two weeks, he noticed decreased radicular symptoms. By late June the patient had no back pain, and his range of motion had improved. By July he was able to lift $100 \mathrm{lbs}$ on an occasional basis. He gradually lost 50lbs of body fat, and was able to walk and stand straight, with full painless ROM. By August he was interviewing for work and was able to return to work. He was enthusiastic about the role a plantbased diet (in conjunction with rehabilitation) had in treating his chronic pain.

\section{Discussion}

Treatment of chronic pain often includes opiates which carry the risk of addiction along with significant side effects. However, treatment with a plant-based diet is a low risk and low-cost option, with no adverse reactions and no contraindications, that can be very effective for several pathologies with pain as a major symptom. It's also a safe and efficacious treatment for comorbid diseases such as coronary artery disease and type II diabetes mellitus. The physician should explain the benefits and offer guidance on implementing a plant-based diet to patients suffering from relevant chronic pain condition. This treatment can be used as a monotherapy or as an adjunct to standard treatment.

\section{References}

1. Schappert S, Burt CW (2006) Ambulatory care visits to physician offices, hospital outpatient departments, and emergency departments: United States, 2001-02. Vital Health Stat 13 2006(159): 1-66.
2. Gureje O, Von Korff M, Simon G, Gater R (1998) Persistent pain and well-being: a World Health Organization Study in Primary Care. JAMA 280(2): 147-151.

3. Smith B, Elliott A, Chambers W, Smith W, Hannaford P, et al. (2001) The impact of chronic pain in the community. Fam Pract 18(3): 292-299.

4. Interagency Pain Research Coordinating Committee (2016) National Pain Strategy: a comprehensive population health-level strategy for pain. Washington DC: US Department of Health and Human Services, National Institutes of Health.

5. Dahlhamer J, Lucas J, Zelaya C, Richard Nahin, Sean Mackey, et al. (2018) Prevalence of Chronic Pain and High-Impact Chronic Pain Among Adults - United States, 2016. MMWR Morb Mortal Wkly Rep 67(36): 1001-1006.

6. Towery P, Guffey J, Doerflein C, Stroup K, Saucedo S, et al. (2018) Chronic musculoskeletal pain and function improve with a plant-based diet. Complement Ther Med 40: 64-69.

7. Rose S, Strombom A (2018) Rheumatoid Arthritis - Prevention and Treatment with a Plant-Based Diet. Orth \& Rheum Open Access J 13(1): 555852.

8. Crane M, Sample C (1994) Regression of Diabetic Neuropathy with Total Vegetarian (Vegan) Diet. Journal of Nutritional Medicine 4(4): 431-439.

9. Strombom A, Rose S (2017) The prevention and treatment of Type II Diabetes Mellitus with a plant-based diet. Endocrin Metab Int J 5(5): 00138.

10. Høstmark A, Lystad E, Vellar O, Hovi K, Berg JE, et.al. (1993) Reduced plasma fibrinogen, serum peroxides, lipids, and apolipoproteins after a 3-week vegetarian diet. Plant Foods for Human Nutrition. Jan 43(1): 55-61.

11. Donaldson M, Speight N, Loomis S (2001) Fibromyalgia syndrome improved using a mostly raw vegetarian diet: an observational study. BMC Complementary Alternative Medicine 1: 7.

12. Kaartinen K, Lammi K, Hypen M (2000) Vegan diet alleviates fibromyalgia symptoms. Scand J Rheumatol 29(5): 308-313.

13. Rose S, Strombom A (2018) A comprehensive review of the prevention and treatment of heart disease with a plant-based diet. J Cardiol \& Cardiovas Ther 12(5): 555847.

\section{Your next submission with Juniper Publishers} will reach you the below assets

- Quality Editorial service

- Swift Peer Review

- Reprints availability

- E-prints Service

- Manuscript Podcast for convenient understanding

- Global attainment for your research

- Manuscript accessibility in different formats

( Pdf, E-pub, Full Text, Audio)

- Unceasing customer service

Track the below URL for one-step submission https://juniperpublishers.com/online-submission.php 